Prima: Jurnal Pendidikan Matematika

Vol. 6, No. 1, January 2022, pp. 53-69

P-ISSN: 2579-9827, E-ISSN: 2580-2216

Web: http://jurnal.umt.ac.id/index.php/prima

\title{
ANALYSIS OF HIGH SCHOOL STUDENTS LOGICAL-MATHEMATICAL THINKING ABILITY BASED ON THE POLYA STAGE SOLVING IN TERMS OF MATHEMATICAL SELF-CONCEPT ABILITY
}

\author{
Rika Mulyati Mustika Sari ${ }^{1}$, Nanang Priatna ${ }^{2}$, Dadang Juandi ${ }^{3}$ \\ Universitas Singaperbangsa Karawang ${ }^{1}$ \\ FMIPA Universitas Pendidikan Indonesia2,3 \\ rika.mulyatimustika@fkip.unsika.ac.id
}

\begin{abstract}
This research is based on the importance of logical-mathematical thinking skills in solving logical-mathematical problems. The research purpose is to describe high school students' logical thinking abilities on geometric transformation material in terms of mathematical self-concepts. The research used a qualitative approach, with the research subject as many as six students of 12th grades science class from one of Bandung Regency high schools selected by sampling technique. Students' logical thinking ability is known from the test scores in solving compiled problems. The score refers to logical-mathematical thinking ability indicators, and the problem-solving technique refers to the Polya stages. Data analysis techniques used are data reduction, data presentation, descriptive statistical calculations, and conclusions/verification. The results showed that the overall students' logical-mathematical thinking ability in the geometry transformation material is in the medium category. In the self-concept category, subjects with high self-concept can fulfil logical thinking questions based on Polya stages. As for subjects with moderate self-concept, the students can only fulfil several indicators of logical-mathematical thinking skills with problem-solving techniques. The result is still not perfect refer to the Polya stage. As for the subject with low self-concept, almost all Polya stages are not fulfiled. The students in the low self-concept category answered the questions incompletely. They had difficulty understanding the problem and planning a solution so that their answers did not match the questions.
\end{abstract}

Keywords: Logical-mathematical Thinking Ability, Mathematical Self-concept, Polya, Geometric Transformation

\begin{abstract}
Abstrak
Penelitian ini dilatarbelakangi pentingnya kemampuan berpikir logis matematis dalam menyelesaikan permasalahan soal matematika yang berhubungan dengan logika. Penelitian ini bertujuan untuk mendeskripsikan kemampuan berpikir logis siswa SMA pada materi transformasi geometri ditinjau self-concept matematis siswa. Pendekatan yang digunakan adalah pendekatan kualitatif dengan subjek penelitian siswa kls XII MIPA di salah satu SMA Negeri Kabupaten Bandung sebanyak 6 siswa yang yang dipilih menggunakan teknik purposive sampling. Kemampuan berpikir logis siswa dilihat dari nilai tes yang diperoleh dalam penyelesaian soal yang telah disusun dengan mengacu pada indikator kemampuan berpikir logis matematis dengan teknik penyelesaian masalah mengacu pada tahapan polya. Teknik analisis data yang digunakan dalam penelitian ini meliputi reduksi data, penyajian data, perhitungan statistika deskripstif dan penarikan kesimpulan/verifikasi. Hasil penelitian menunjukkan bahwa secara keseluruhan kemampuan berpikir logis matematis siswa pada materi transformasi geometri berada pada kategori sedang. Sedangkan jika ditinjau dari kategori self concept, subjek dengan self concept tinggi mampu memenuhi semua penyelesaian soal berpikir logis berdasarkan tahapan polya. Adapun subjek dengan self concept sedang, siswa tersebut hanya mampu memenuhi beberapa indikator kemampuan berpikir logis matematis dengan teknik penyelesaian masalah yang mengacu pada tahapan polya masih belum sempurna. Kemudian, subjek dengan self concept rendah hampir semua tahapan polya belum terpenuhi, subyek pada kategori ini memberikan jawaban belum lengkap dikarenakan siswa tidak dapat memahami permasalahan dan tidak dapat merencanakan penyelesaian sehingga mereka memberikan jawaban yang tidak sesuai dengan pertanyaan.
\end{abstract}

Kata kunci: Kemampuan Berpikir Logis Matematis, Self Concept Matematis, Polya, Transformasi Geometri

Received: November 11, 2021; Revised: December15, 2021; Accepted: January 20, 2022 


\section{INTRODUCTION}

The focus of achievement in learning mathematics is not only oriented to material mastery. The material is a tool to achieve competence. The scope of school mathematics learning is adjusted to the competencies that students must be achieved. Referring to competency standards and basic competencies, the scope of mathematics material in schools includes algebra, measurement and geometry, probability and statistics, trigonometry, and calculus. According to NCTM (2000), there are five standard contents in mathematics, namely numbers and their operations, algebra, geometry, measurement, and data and probability analysis.

Geometry, one of the tools of scientific thinking, is important to include in the mathematics learning process. It is beneficial in educational activities both in geometry fields and its application to other sciences fields. Shwartz (2010) stated that geometry is a concept that connects various mathematics fields. Geometry topics for elementary, middle, and high school levels have been included in the mathematics curriculum for a long time (Fauvel, Jhon, Maaenan \& Van; 2002). The scope of learning geometry in primary and secondary schools has different levels. The topic of geometry for the high school level is contained in the 2013 Curriculum, which has used a lot of logic and reasoning to make decisions. The purpose of providing geometry material is students can make decisions, determine strategies, find concepts, and communicate concepts obtained during learning activities.

The abilities possessed by students in studying geometry must refer to the 2013 Curriculum standards. One of the standards is that students are expected to have logical-mathematical thinking abilities. Logical thinking ability is important to support math and science skills. According to Puspitasari (2019), logical-mathematical thinking ability can improve student learning outcomes on mathematical concepts. Syawahid $(2015: 138)$ explained that logical thinking is an individual's ability to solve problems referring to the strong validity of primary procedures, not only based on existing procedures. Based on the details from Sumarmo (2006), logical-mathematical thinking ability is divided into several components: (1) Proportional reasoning, the ability to determine and compare ratios; (2) Variable control, the ability to plan, implement, and interpret information; (3) Probability reasoning, the ability to interpret the data obtained in the form of the probability of an event occurrence; (4) 
Correlational reasoning, the ability to determine whether two events/variables are related;

(5) Combinatorial reasoning, the ability to determine the combination of an event.

Sumarmo (2012:19) described other several indicators of logical thinking ability, namely students can: (1) Conclude or make predictions and interpretations based on appropriate proportions (generalizations); (2) Conclude or make predictions based on opportunities; (3) Conclude or make predictions based on the correlation between two variables; (4) Determine the combination of several variables; (5) Conclude from the equation of the two processes (analogy); (6) Prove it; (7) Organize the analysis and synthesis of several cases. Based on these indicators, the researcher concludes that the logical thinking indicator is related to the transformation geometric material. Logical thinking skills indicators used in this research are as follows:

Table 1.

Indicator of Logical-Mathematical Thinking skills

\begin{tabular}{|c|c|c|}
\hline Component & Indicator of logical thinking & Question indicator \\
\hline $\begin{array}{l}\text { Proportional } \\
\text { reasoning }\end{array}$ & $\begin{array}{l}\text { The skills to solve proportion or } \\
\text { ration problem with variety of } \\
\text { strategies. }\end{array}$ & $\begin{array}{l}\text { Students can solve the problem } \\
\text { regarding the ratio of transformation } \\
\text { result (reflection and rotation) with } \\
\text { variety of strategies. }\end{array}$ \\
\hline $\begin{array}{l}\text { Correlation } \\
\text { reasoning } \\
\text { (Analogy) }\end{array}$ & $\begin{array}{l}\text { the skills to find similarities of } \\
\text { relationship in certain image } \\
\text { pattern. }\end{array}$ & $\begin{array}{l}\text { Students can choose the most correct } \\
\text { statement and explain it from a picture } \\
\text { on cartesian coordinate determining the } \\
\text { relationship between several } \\
\text { occurrences on the image that could } \\
\text { happen from the result of } \\
\text { transformations }\end{array}$ \\
\hline $\begin{array}{l}\text { Generalizatio } \\
\mathrm{n}\end{array}$ & $\begin{array}{l}\text { The skills to draw a general } \\
\text { conclusion from the } \\
\text { relationship between image } \\
\text { pattern }\end{array}$ & $\begin{array}{l}\text { Students can draw a general conclusion } \\
\text { from several relationships of a circle } \\
\text { result reflection composition with its } \\
\text { reflection }\end{array}$ \\
\hline
\end{tabular}

The result from the elaboration of those indicators is that the skill of thinking logically is very necessary for the students whether when learning in the class, having a group discussion and solving problems that needed skills to associate certain problems that could be understood 
by logic. That thing is in line with Erihadiana's statement (Octaria, 2017) that students need to master the skills to think systematically, especially thinking logically and scientifically in solving problem surrounding math.

One of the aspects that the students will need to improve their math skills, specifically the skills to think logically is through mathematics self-concept. Self-concept in general can be interpreted as the way someone perceives themselves. This perception is affected by several things which are environmental influence and the tendency from the people around the students. Someone who has a good self-concept will show good self-confidence as well. This is because self-concept is one of the factors that built someone's confidence, especially in education (Shavelson \& Bolus, 1982). Another term for self-concept is konsep diri. Selfconcept developed from someone's experience regarding various things about themselves since their childhood (Djaali, 2006).

Based on the explanation on the importance of logical-mathematical thinking in learning mathematics and the importance of self-concept in the development of student's mathematical abilities, the authors are moved to analyze student's skills in solving logical thinking problems through Polya problem-solving stages reviewed from students' self-concept categories. According to Polya (1973:5), there are four stages that can be done to solve a problem, which is (1) understanding the problem; (2) planning on problem-solving; (3) carry out the plan; and (4) reviewing the completion of the problem-solving.

\section{METHODS}

The type of research used is qualitative research by using a descriptive method, which is a kind of research that seeks to describe or describe a phenomenon, event, or situation that is being studied deeply. The analysis that is studied in depth is the mathematical logical thinking skills. The technique to determine the subject in this study is purposive sampling. The subject of this research is the eleventh-grade high school students who have learned geometry transformation. The subject of this research is selected based on the self-concept categories as well as several other considerations to choose which students will be interviewed.

The data collection technique that is used in this research is through testing. The instrument of the research consists of three questions about mathematical logical thinking skills in geometry transformation topic and a questionnaire about students' mathematical self- 
concept. The three logical thinking skills questions are already tested and can be used because it has been tested for validity, reliability, differentiation, and an adequate level of difficulty.

\section{RESULTS AND DISCUSSION}

The test of students' logical thinking skills in solving problems on the topic of Geometry Transformation is given to the selected subjects to be resolved by them later. The following are the description of the students' logical thinking skills in solving logical thinking problems of geometry transformation.

\section{Question 1:}

Arectangular $A B C D$ with coordinate $A(1,0) B(-1,0) C(-1,1)$ dan $D(1,1)$ dilated by $[(0,0), k=3]$ continued with rotation $[R(0,0), \beta=1 / 2 \pi]$ produce a reflection construction $A^{\prime} B^{\prime} C^{\prime} D^{\prime}$. What is the ratio of the perimeter and area of the two figures before and after!

\section{Question 2:}

Based on the image below, there are several student's result analysis on the image, including:

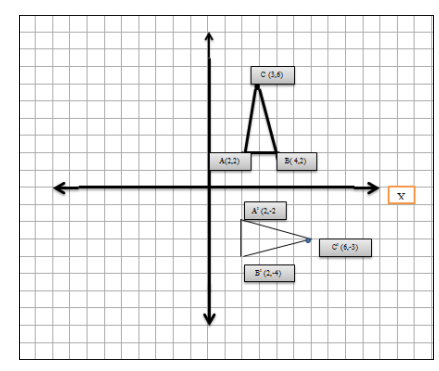

- According to Anna, triangle $A^{\prime} B^{\prime} C^{\prime}$ is a reflection from $90^{\circ}$ rotation of $A B C$ triangle counterclockwise

- According to Rina, triangle $A^{\prime} B^{\prime} C^{\prime}$ is the reflection from $270^{\circ}$ rotation of $A B C$ triangle 
- According to Anti, triangle $A^{\prime} B^{\prime} C^{\prime}$ is the reflection of the line's reflection of $y=-x$ from $A B C$ triangle

From the three student's statement above, which one do you think is the most appropriate and gives the explanation!

\section{1) Understand the problem}

The indicator of logical thinking includes stages on understanding and planning a solution. The following are the results of the analysis of student AA from several techniques on questions number one and number two.

a) Test technique

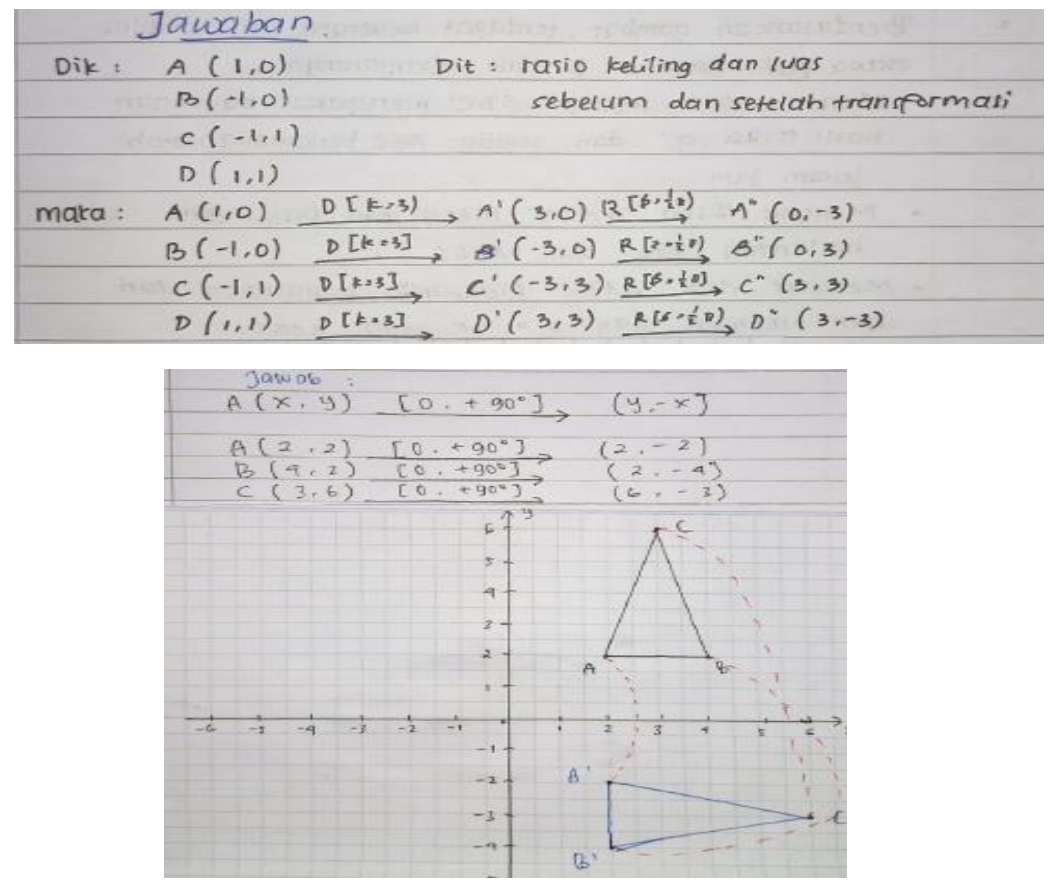

Figure 1. Questions "AA 1"

Based on the result of student AA's solution on question number one and question number two, students who have high self-concept, which is student $A A$, at the stage of understanding the problem, AA could understand the information so that AA could create a modeling before going to the next stage. This shows that the planning stages were successfully passed, where students AA designed the model first and in question number two, drew the rotation direction of the triangle construction.

b) Observation Result

In the observations done by the researcher, the researcher saw that student AA felt confused when working on the questions given. Student AA looked around asking for help 
from his friend. It can be known that student AA could fulfill the stages of understanding problems, according to problem-solving indicators based on Polya's steps (Polya, 1973). Then at the stage of planning the problem, student AA managed to work on it but there is still inaccuracy in the modeling. So, it can be concluded that student AA on the logical thinking indicator at the stage of understanding the problem and planning the problem of thinking coherently could be fulfilled but still lacking. This happened because students' thinking skills were lacking due to their process of thinking on understanding questions were through trial strategy and in the process of solving the questions, they were not being careful because there was one missing step that forgot to be written (Tohir, Susanto, et al., 2018).

\section{2) Problem-solving}

The next stage of indicators of logical thinking is problem-solving. The following are the analysis results of student AA from the problem-solving stage in questions number one and number two.

a) Test technique

The following are the results of student AA, who has high self-concept abilities. 

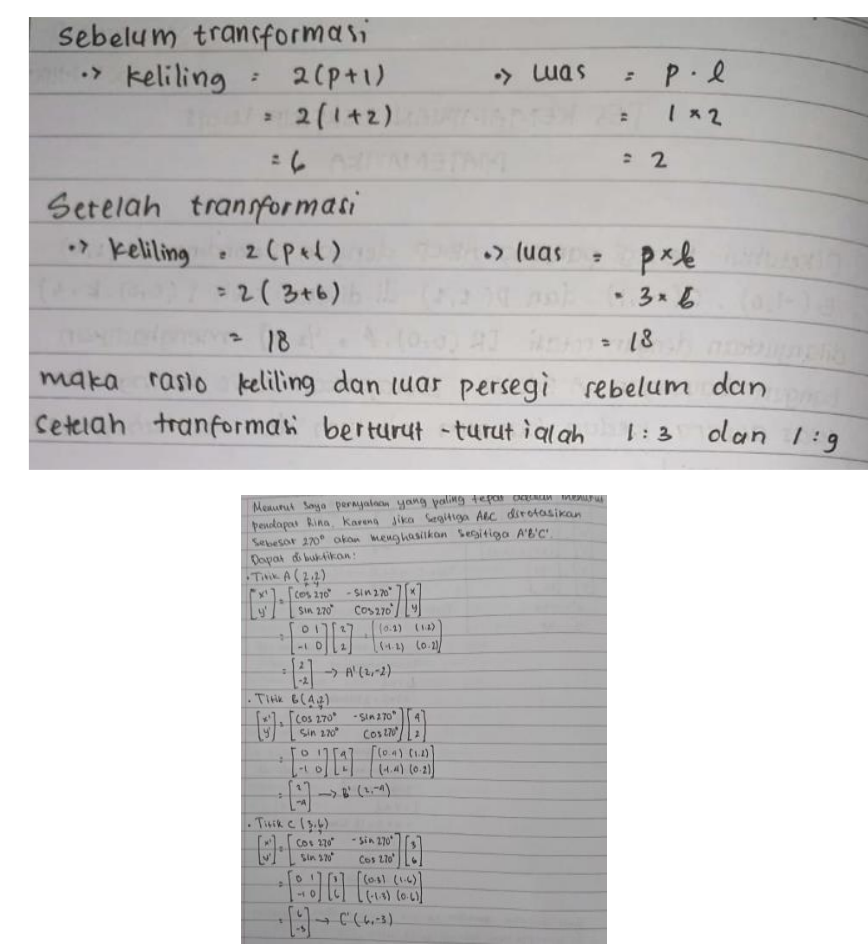

Figure 2. Questions "AA 2"

From the results above, it can be seen that student $A A$, in answering questions number one and number two, only did half of the step where the student planned to answer the question by finding the area and the perimeter but did not succeed in determining the ratio. Moreover, in solving question number two, student AA had not succeeded in completing the work thoroughly.

b) Observation Results

In this technique, it can be seen that student AA was confused in solving the questions given. The student tried to ask their friend how or what steps to take to find the correct answer. Moreover, student AA was found looking around at their friends' answer sheets. Therefore, it can be concluded that student AA has not been able to meet the argumentation skills stage on logical indicators and problem-solving indicators based on Polya's steps at the stage of solving problems. This happens due to the student's ability to solve problems based on their previous ideas (Tohir, Susanto, et al., 2018). 
3) Re-checking (Withdrawal of conclusions)

a) Test technique
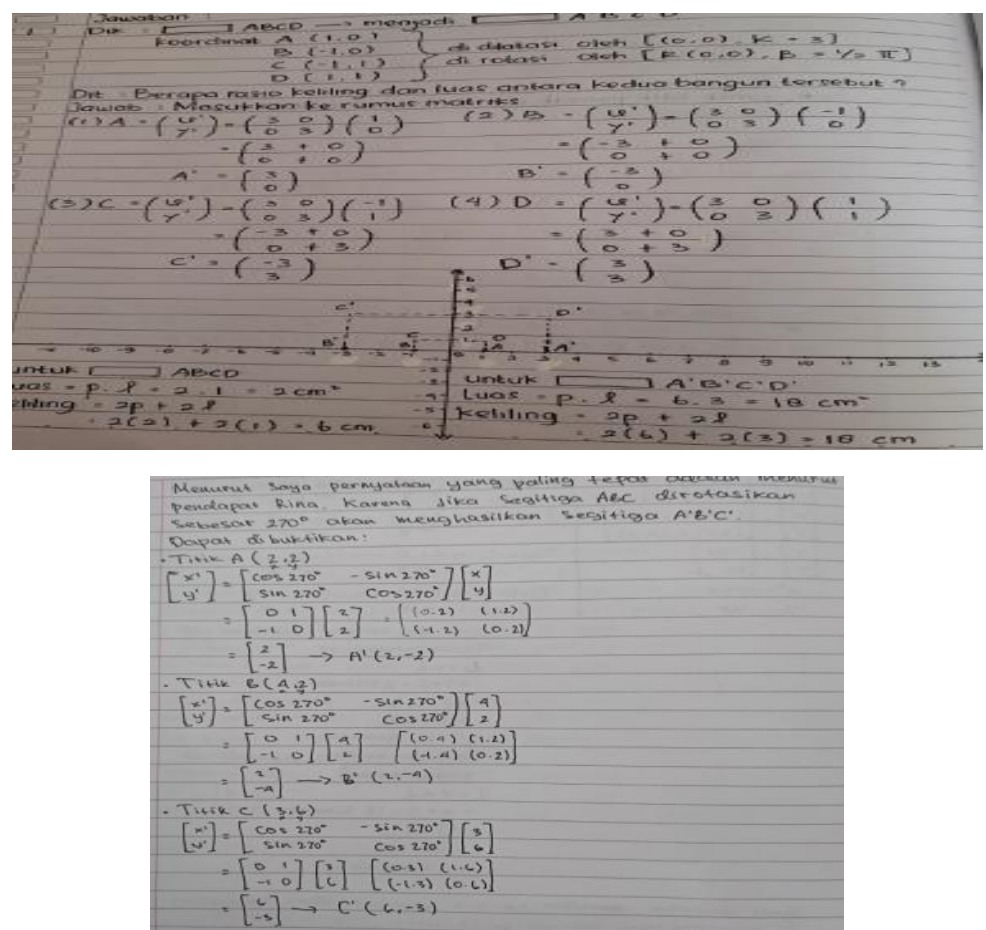

Figure 3. Questions "AA 3"

From the test results on the answer sheets number one and number two, it appears that student AA did not write conclusions, nor did they re-check to ensure whether the answers, if put into one of the equations, matched the results of the equation. As the student did not complete the steps in the problem-solving stage until he finished and found the answer, the student could not carry out the last stage, which is re-checking.

b) Observation technique

From the observations, student AA seemed confused in finding the expected answer. Thus, the student did not finish and re-check his work. It means that student AA was not able to meet the indicators of logical thinking, namely concluding, as well as to do the re-checking step in the problem-solving indicators based on Polya's steps. 
2. Logical thinking ability of student BB who has a moderate self-concept ability in solving problems on matrix application material on geometric transformations

The following are the results of the problem solving of student $\mathrm{BB}$, who has a moderate self-concept ability.

\section{1) Understanding the problem}

Indicators of logical thinking 'coherence of thinking' include the stages of understanding the problem and planning a solution. The following are the results of student BB's analysis of several techniques on questions number one and two.

a) Test techniques

The following are the results from student BB.
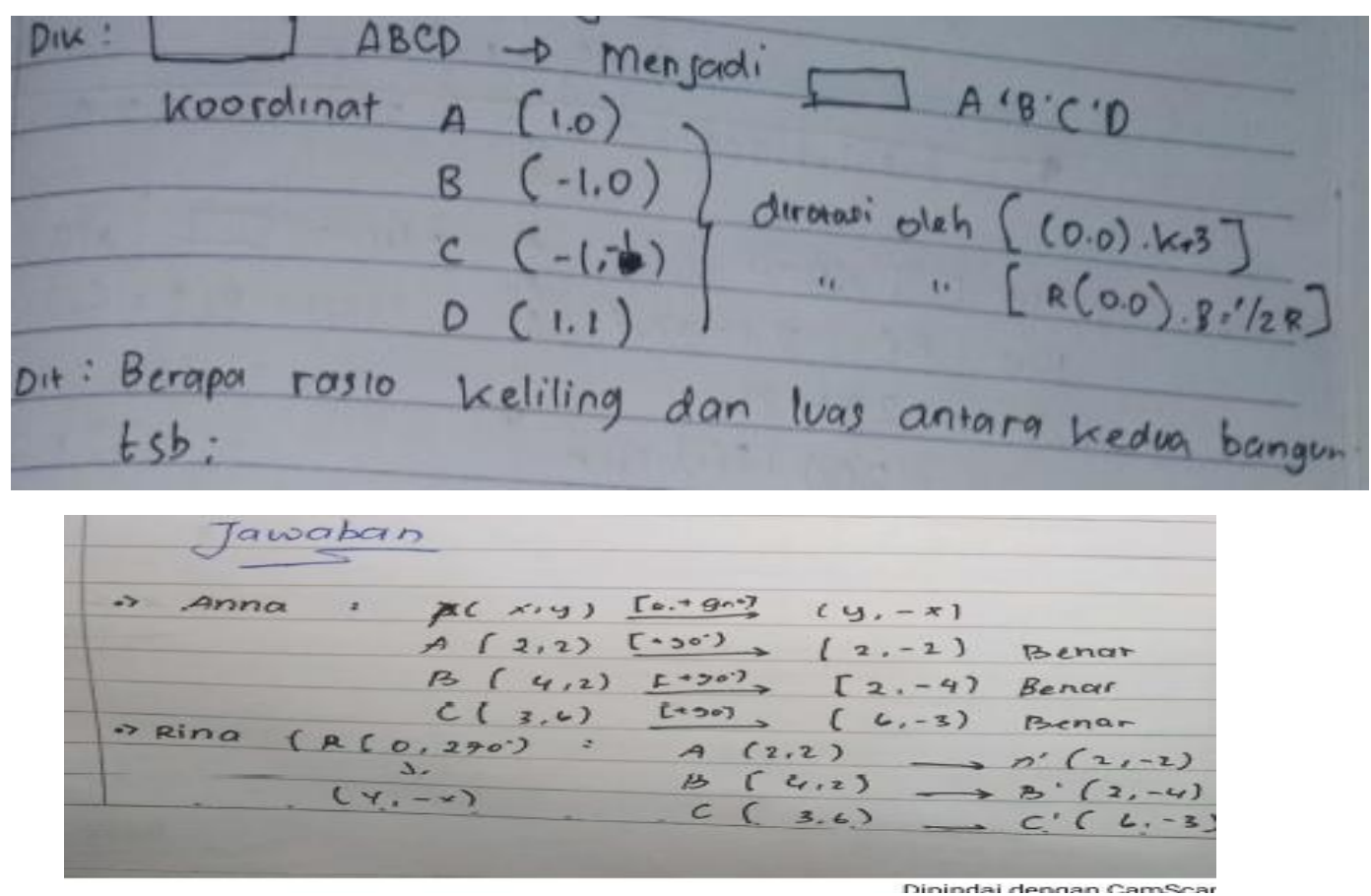

Figure 4. Questions "BB 1"

From the results of student BB's problem solving of questions number one and two, it can be seen that the student understood the information contained in the questions well so that the student was able to write down the elements that they knew and the elements that were asked. 
b) Observation technique

In this technique, the researcher records directly what is seen, heard, and felt. In the observation technique, the researcher saw that student BB seemed to understand very well the information obtained from the questions as they mentioned what was asked and knew in the questions. Student BB was able to fulfil the stage of understanding the problem in problem-solving indicators based on Polya's steps. Moreover, at the stage of planning problem-solving, student BB managed to answer the questions. Therefore, it can be concluded that student BB was able to fulfil the indicators of logical thinking stages of understanding the problem and planning problem-solving. The results of this study are in line with the results of research conducted by Tohir (2018), which shows that students with high abilities at the stage of identifying the problems choose the information needed and information that is not needed in solving problems correctly.

\section{2) Planning problem-solving}

Indicators of logical thinking 'coherence of thinking' include the stage of solving problems.

a) Test technique

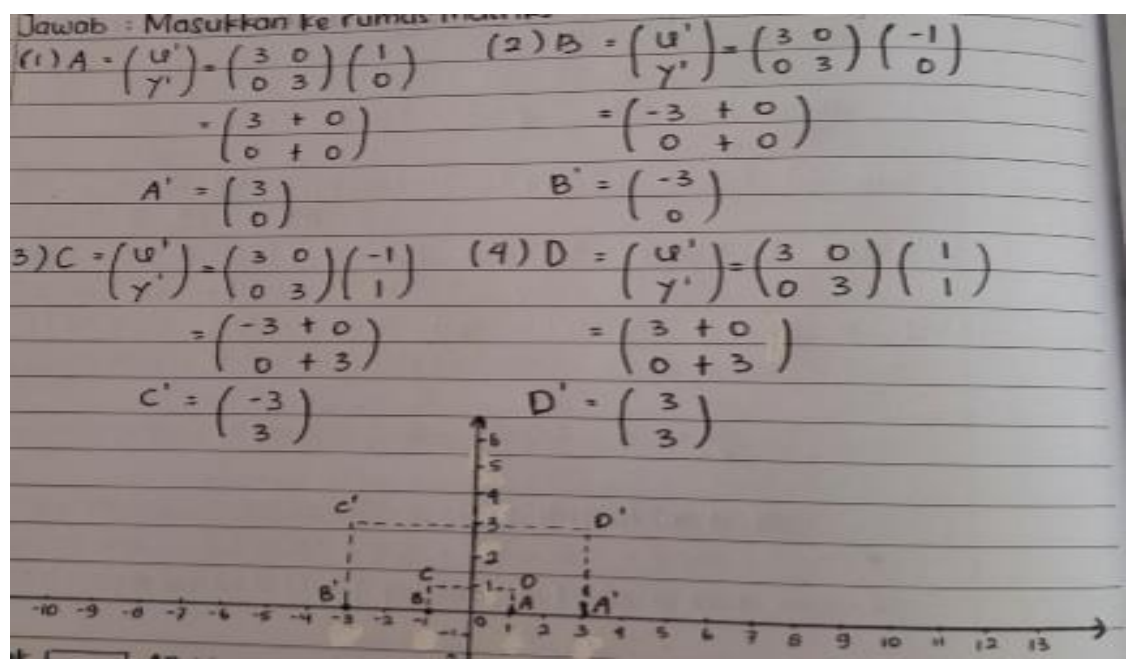

Figure 5. Questions “BB 2"

Analysis Of High School Students Logical-Mathematical Thinking Ability Based On The Polya Stage Solving In Terms Of Mathematical Self-Concept Ability Sari, Priatna, Juandi 
From the results of question number one, it is found that at the planning problemsolving stage, student BB managed to answer the question using the matrix method, where the student used the matrix addition concept to find the results and the imaginary results. Then, the student described points on Cartesian coordinates, which indicate the next step.

Therefore, it can be concluded that student BB was able to fulfil the indicators of logical thinking stages of understanding the problem and planning problem-solving. The results of this study are in line with the research conducted by Tohir (2017), which shows that students with high abilities at the stage of identifying the problems choose the information needed and information that is not needed in solving problems correctly.

b) Observation technique

In the observation technique, the researcher saw that when student BB tried to answer the question, student BB looked very confident in the initial process. However, in the middle of the process, student BB seemed confused about continuing the steps but still tried to answer the question.

\section{3) Doing re-checking}

The following are indicators of logical thinking in drawing conclusions which include rechecking some of the techniques used.

a) Test technique

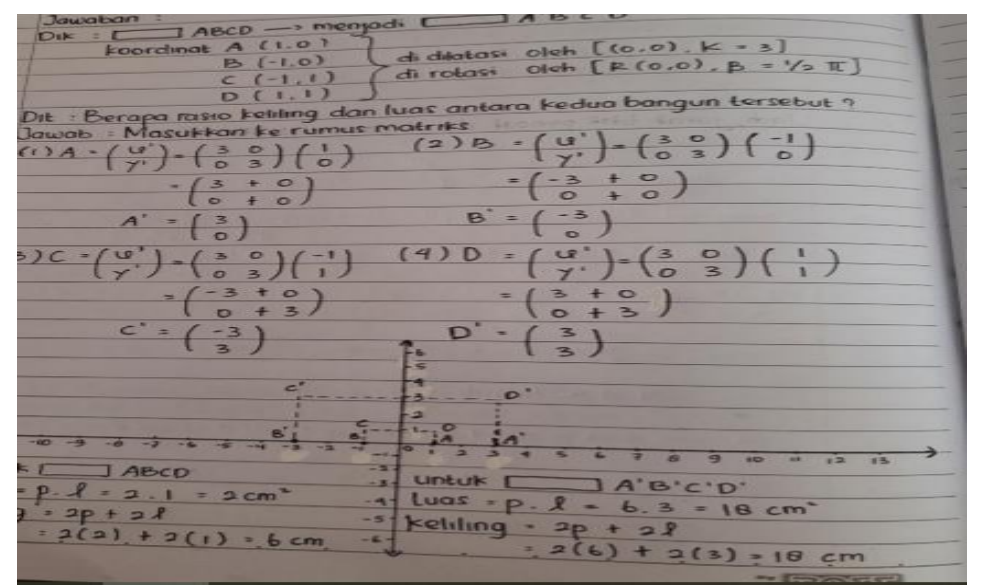




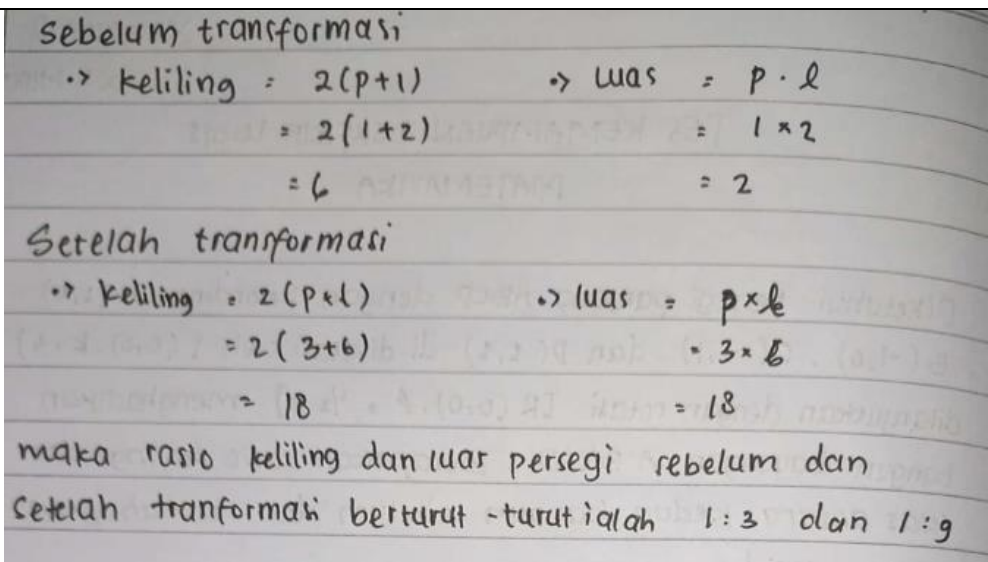

Figure 6. Questions “BB 3"

It is known that in the results of the answers made by students, student BB did not carry out the stages of re-checking, but student BB could conclude until the end of the comparison or ratio of the area and perimeter of the shape. The student felt the steps were right in solving the problem given, and at the same time being able to finish it until the end.

b) Observation technique

In the observation technique, it was seen that student BB seemed to work on the questions very easily, the student was confident and seemed relaxed but sure when solving the problems given. When the researcher looked at the answer sheet, the student BB writing was very neat and it looked like the student was working in a coherent manner as if the students was used to working on the model questions. It was concluded that student BB could fulfil the indicators of logical thinking, namely drawing conclusions and being able to re-check the problem-solving indicators as well based on Polya's steps but it was not written on the answer sheet because they were sure that the answers were correct.

3. Logical thinking ability of student CC who has low self-concept ability in solving problems on matrix application materials on geometric transformations

\section{1) Understanding the problems}

a) Test technique 

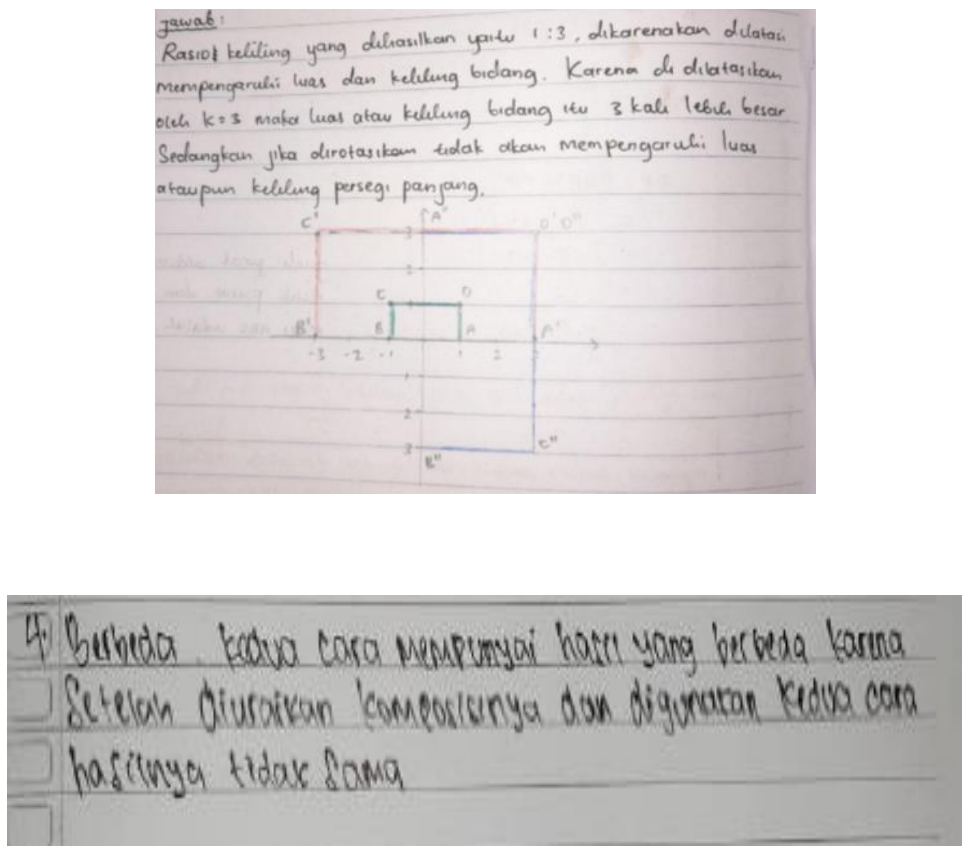

Figure 7. Questions “CC"

It is known that in the results of the answers made by students, student CC did not carry out the stages of re-checking, but student BB could conclude until the end of the comparison or ratio of the area and perimeter of the shape. The student felt the steps were right in solving the problem given, and at the same time being able to finish it until the end.

b) Observation technique

In the observations of students CC conducted by the researcher, when the time was up, the student immediately collected the results of the work to the researcher without re-correcting. Since time had already been declared, the student felt he could not justify his answer. So finished or not, it still had to be collected. In question number one, it appeared that CC did not write down the results of the answer, and in question number two, CC could not understand the problem so that they could not proceed to the next stages, namely planning for understanding the problem and re-checking. 


\section{CONCLUSION}

Based on the results of data analysis and discussion of mathematical logical thinking skills, in terms of high school students' self-concepts, three things can be concluded. First, students with high self-concept category have high logical-mathematical thinking ability. Students can fulfil all the completion steps of the Polya stages with the results of their work systematically and understand the problem well. However, there are still students who are not careful in understanding the questions so that there is an error in re-checking; students do not write conclusions or re-check to make sure whether the answers obtained, when they are substituted into one of the equations, match the results of the equation or not. Second, students with moderate self-concept category have moderate logical-mathematical thinking skills. Students who have moderate self-concept can fulfil two indicators of logical thinking, coherence of thinking and ability to reason. In addition, they can meet the three indicators of problem-solving but are still lacking and less able to solve problems because they only do half the steps. The students manage to plan the solution but fail in completing it. This is due to unfinished problem-solving and lack of expressing ideas using their own language. Third, students with low self-concept category have low logical-mathematical thinking skills. Students who have low self-concept meet one indicator of logical thinking and meet two indicators of problem solving but are still lacking, where students have not been able to understand problems and plan solutions and communicate the results of their work systematically.

Students are more likely to give answers in a concise manner and without a clear explanation so that there are still errors in the answers and are unable to express ideas using their own language as well.

\section{ACKNOWLEDGMENTS}

Thank you to the promoter, Prof. Dr. H. Nanang Priatna, and co-promoter, Dr. Dadang Juandi, for the guidance and knowledge in the development of this article.

Analysis Of High School Students Logical-Mathematical Thinking Ability Based On The Polya Stage Solving In Terms Of Mathematical Self-Concept Ability Sari, Priatna, Juandi 


\section{REFERENCES}

Djaali. (2006). Psikologi Pendidikan. Bumi Aksara

Polya, G. (1973). How to Solve It. A New Aspect of Mathematical Method. New Jersey: Princenton University Press.

Puspitasari, I.W., Fauzan, G.A., \& Bernard, M. (2019). Penerapan PBL dengan RME Berbantuan Software Geogebra untuk Meningkatkan Kemampuan Berpikir Logis Matematik Siswa. Jurnal On Education, 1(4), 679-687

Shavelson, R. J., \& Bolus. (1982). Self-Concept: The Interplay of Theory and Methods. Journal of Educational Psychology, 74(1).

Sumarmo, U. (2006). Kemandirian Belajar: Apa, Mengapa Dan Bagaimana Dikembangkan pada Peserta Didik. Makalah disajikan pada Seminar Pendidikan Matematika di UNY tahun 2006 dan dilengkapi untuk bahan ajar Perkuliahan Isu Global dan Kajian Pendidikan Matematika di SPs UPI Februari 2011.

Sumarmo, Utari, dkk. 2012. Kemampuan dan Disposisi Berpikir Logis, Kritis dan Kreatif Matematik (Eksperimen Terhadap Siswa SMA Menggunakan Pembelajaran Berbasis Masalah dan Strategi Think Talk Write). Jurnal Pengajaran MIPA, Volume 17 (Nomor 1, April 2012). 17-33.

Syawahid, M. 2015. Kemampuan Berpikir Formal Mahasiswa. Beta Jurnal Pendidikan Matematika. Vol. 8 No.2 (Nov) 2015 Hal. 137-153; ISSN 2085- 5893. http://ejurnal.iainmataram.ac.id/index.php/beta

Thalhah, S. Z., Tohir, M., Nguyen, P. T., Shankar, K., \& Rahim, R. (2019). Mathematical Issues in Data Science and Applications for Health care. International Journal of Recent $\begin{array}{lllll}\text { Technology and } & \text { Engineering, }\end{array}$ https://doi.org/10.35940/ijrte.B1599.0982S1119 
Tohir, M., Maswar, M., Atikurrahman, M., Saiful, S., \& Pradita, D. A. R. (2020). Prospective Teachers' Expectations of Students' Mathematical Thinking Processes in Solving Problems. European Journal of Educational Research, 9(4), 1735- 1748. https://doi.org/10.12973/eu-jer.9.4.1735

Tohir, M., Susanto, Hobri, Suharto, \& Dafik. (2018). Students' Creative Thinking Skills in Solving Mathematics Olympiad Problems Based on Problem-Solving Polya and Krulik-Rudnick Model. Advanced Science Letters, 24(11), 8361-8364. https://doi.org/10.1166/asl.2018.12563 